\title{
EXPRESSÕES ESTEREOTIPADAS E ESTRUTURA TEXTUAL
}

\section{Jamir Soriano Teixeira}

\section{INTRODUÇÃO}

De acordo com Halliday (1985), o texto é uma unidade semântica, um evento interativo, uma troca com significado social em um contexto de situação particular. Por se tratar de uma atividade humana mediada pela linguagem, essa relação de trocas significativas em determinado contexto permite aos envolvidos no processo comunicativo fazer predições garantindo a unidade significativa desse evento.

Segundo Kleiman (2000, p. 52):

... o leitor eficiente faz predições baseadas no
seu conhecimento de mundo. Na aula de
leitura é possível criar condições para o aluno
fazer predições, orientado pelo professor, que
além de permitir-lhe utilizar seu próprio
conhecimento, supre eventuais problemas de
leitura do aluno, construindo suportes para o
enriquecimento dessas predições e mobilizando
seu maior conhecimento sobre o assunto.

Uma das possibilidades de estratégias de leitura é a imersão no texto para se verificar a construção do texto em blocos semânticos a fim de se fazer predições sobre a estrutura textual. Essas estratégias permitem ao leitor a reconstrução das condições macroestruturais nas quais o texto foi produzido pelo autor, assim como, verificar a importância de itens lingüísticos que sustentam os movimentos dos blocos semânticos no texto.

O objetivo deste trabalho é explorar as recorrências das Lexical Phrases modalizadoras, aqui traduzidas como Expressões Estereotipadas (EEs) pode + infinitivo (ativo ou passivo) $X /$ é possível $X$; deve + infinitivo (ativo ou passivo) $X$ / é necessário X e a inter-relação desses itens lingüísticos com os blocos que formam a macroestrutura dos exemplares textuais escolhidos para esta análise.

Lexical Phrases, segundo Nattinger e DeCarrico (1997), são fenômenos lexicais freqüentes na língua, de extensão variada e estrutura fixa ou variável. Essas expressões cristalizadas incluem 
sintagmas curtos relativamente fixos e sintagmas mais longos de estrutura básica e fixa com ou sem lacunas para serem preenchidas. São considerados compostos de forma + função, isto é, apresentam uma forma e desempenham determinadas funções no texto.

\section{METODOLOGIA ADOTADA}

Dentro da metodologia tipológico-descritiva, foram selecionados exemplares do corpus de um levantamento (ainda não totalmente concluído) quanto ao uso/função das EEs modalizadoras pode + infinitivo (ativo ou passivo) $X$ I é possível $X$; deve + infinitivo (ativo ou passivo)X / é necessário $X$. Esses exemplares fazem parte de um corpus de cerca de trinta textos retirados da Internet, seções Equilíbrio Online e Beleza, da Folha Online. Para este artigo, foram extraídos do corpus e analisados fragmentos pré-determinados quanto às características para verificar qual é a função que exercem na tipologia textual analisada.

Os exemplares que estão sendo analisados apresentam o mesmo padrão textual de estruturação: blocos de informação do tipo Problema-Solução. Os textos tratam dos cuidados com a estética corporal. As EEs procuram apoiar procedimentos de persuasão modalizando deôntica ou epistemicamente. A mesma EE tem função diferente conforme o bloco semântico (problema ou solução) em que aparece. Esse item lingüístico mantém aparentemente uma recorrência no bloco semântico em que aparece quanto ao efeito positivo ou negativo. Há também um mesmo tipo de função recorrente relacionada ao grau de força ilocucionária. Assim, se o modalizador lexical for fraco, o ato de fala se torna fraco quanto à força; se o modalizador for forte, o ato de fala resultante é forte.

A seguir mostraremos fragmentos retirados de alguns exemplares que fazem parte do corpus:

\section{- FRAGMENTO 1:}

"Micoses, manchas, infecções e desidratação são doenças que podem fechar o verão para quem não se cuidou nesta estação, que termina nesta semana."

A expressão modalizadora grifada indica uma possibilidade negativa, no bloco problema, para aquelas pessoas descuidadas com a pele na referida estação.

"Podem fechar" (bloco problema - possibilidade negativa): modalizador fraco, ato de fala fraco (epistêmico)

\section{- FRAGMENTO 2:}

"Se a pele estiver ressecada, desidratada ou com manchas, algumas medidas simples podem resolver"

apresenta valor de possibilidade de solução positiva caso ocorra o 
problema acima mencionado.

"Podem resolver" (bloco solução — possibilidade positiva) : modalizador fraco, ato de fala fraco (epistêmico)

- FRAGMENTO 3:

"Ediléia indica banhos mornos e rápidos e o uso de sabonete neutro e de bons hidratantes para apele ressecada. Além disso é necessário fugir do sol por algum tempo."

A expressão modalizadora em destaque "é necessário" com valor deôntico, entre as demais indicações, somada a obrigatoriedade de afastamento temporário à exposição solar, resultaria em fator de solução positiva para o problema.

"È necessário" (bloco solução — solução positiva): modalizador forte, ato de fala forte (deôntico)

\section{- FRAGMENTO 4:}

"Os pés, mais do que hidratação, sofrem com o espessamento da pele, a hiperqueratose. É uma defesa da pele, mas pode incomodar." Embora haja afirmação de que a hiperqueratose é uma defesa da pele, o uso da expressão está ressaltando a possibilidade do efeito negativo dessa defesa.

"Pode incomodar" (bloco problema - efeito negativo) : modalizador fraco, ato de fala fraco (epistêmico)

- FRAGMENTO 5:

"Os tratamentos contra envelhecimento, ruga e acne devem continuar."

A expressão exerce a função de aconselhar para a obtenção dos resultados positivos dos referidos tratamentos (antienvelhecimento, ruga e acne).

"devem continuar" (bloco solução - resultados positivos) modalizador forte, ato de fala forte (deôntico)

\section{- FRAGMENTO 6:}

"mas mesmo assim o tratamento não deve ser interrompido"

A expressão modalizadora exerce a função de aconselhar para a obtenção de resultados positivos.

"deve ser interrompido" (bloco solução — resultados positivos) modalizador forte, ato de fala forte (deôntico)

\section{- FRAGMENTO 7:}

"Se ficar difícil tolerar os produtos porque a pele fica mais sensível, o uso pode ser alternado com hidratante,"

O material grifado indica uma sugestão positiva no bloco solução. "pode ser alternado" (bloco solução — efeitos positivos): modalizador fraco, ato de fala fraco (epistêmico)

- FRAGMENTO 8: 
"O peeling químico malfeito pode causar também intoxicação, sensibilidade ao frio, processos alérgicos..."

A expressão pode causar — bloco problema - indica uma probabilidade de se obter resultados negativos com um peeling malfeito.

"pode causar" (bloco problema - resultados negativos): modalizador fraco, ato de fala fraco (epistêmico)

- FRAGMENTO 9:

"O peeling "lunch time" , por exemplo, não deve produzir esfoliação."

Este modalizador do bloco problema implica a obrigatoriedade da não esfoliação para não se obter resultados negativos.

"deve produzir" (bloco problema - efeitos negativos): modalizador forte, ato de fala forte (deôntico)

\section{RESULTADOS PARCIAIS}

Os resultados até o momento são meramente sugestivos, pois se trata de resultados parciais de um projeto em andamento que analisa as propriedades de uma tipologia textual quanto à presença e função de EEs modalizadoras. Até então, vislumbramos algumas tendências. Espera-se, com a continuidade da pesquisa, poder confirmar essas suposições com a análise do restante do corpus.

\section{CONSIDERAÇÕES FINAIS}

$\mathrm{Na}$ qualidade de analista de estratégias discursivas, cabe ao professor ensinar aos seus alunos, através de estratégias de leitura, como "imergir" em textos para desconstruir e reconstruir o contexto no qual esse texto foi produzido, qual a provável intenção de quem o produziu e quais foram as presumidas condições de produção associadas em função do posicionamento e pistas para a construção de sentidos deixadas pelo autor. Desta forma, considerando Kleiman (2000), a leitura deixa de ser uma mera análise de palavras para passar a ser uma conscientização sobre os usos (e abusos) da linguagem mediante a leitura. Quanto mais proficiente for o leitor, maiores serão as chances de este fazer predições adequadas sobre o texto e, assim, perceber, entre outros fenômenos textuais, as relações específicas contraídas entre determinados itens lingüísticos desse texto (no caso, as EEs) e sua macroestrutura.

\section{BIBLIOGRAFIA:}

HALLIDAY, M. A. K \& R. HASAN. Language, context, and text: aspects of language in a social-semiotic perspective. Oxford: Oxford University Press, 1985.

KLEIMAN, A. Oficina de leitura: teoria e prática. $7^{\mathrm{a}}$ ed. Campinas, SP: Pontes, 2000. 
KOCH, I. GV. Argumentação e linguagem. 6. ed. São Paulo : Cortez, 2000.

NATTINGER J.R. \& DECARRICO,J.S. Lexical phrases and language teaching. 2nd. ed. New York: Oxford University Press, 1997. 